\section{Mercury risk from teeth}

SIR-Mills in Scientific Correspondence' estimated the amount of mercury released into the atmosphere from crematoria. But in the case of the crematorium quoted, Mills assumed that each of the 3,831 people cremated in 1989 had five amalgam fillings in their teeth, based on an estimate ent $^{2}$ that 30 of adults in the United Kingdom had lost all their natural teeth and the rest had 7.5 restorations.

When the age distribution of the population is considered, the total number of deaths in England and Wales in 1988 was 571,408 (ref. 3). Of these, 161,587 $(28.3 \%)$ were under 65 years old and $409,821(71.7 \%)$ were aged 65 and over (24\% aged $65-74$ years and $47.7 \%$ over 75 years). Furthermore, $57 \%$ of the population aged 65-74 years old are edentulous, whereas the corresponding figure for those over 75 years old is $80 \%$ (ref. 4 ). In addition, each of the 59,000 65-74-year olds who has some natural teeth has 5.7 fillings, and only 3.7 tecth have been restored in each of the 54,500 people over 75 years of age.

If we assume that all the fillings are of amalgam, then the weight of mercury released from the 65-74-year-old group is $59,000 \times 5.7 \times 0.6 \mathrm{~g}$, or $201,780 \mathrm{~g}$, and $54,500 \times 3.7 \times 0.6 \mathrm{~g}$, or $120,990 \mathrm{~g}$, from those over 75 years. The number of people under the age of 65 who died was 161,587, each of whom had approximately nine fillings. This accounts for $161,587 \times 9 \times$ $0.6 \mathrm{~g}$, or $872,570 \mathrm{~g}$, of mercury.

Thus, the maximum weight of mercury released annually in England and Wales is $482 \mathrm{~kg}$. This is a generous estimate as not all restored teeth are of amalgam. Another fact which reduces this figure is that only $68 \%$ of the population are cremated. Hence, the total amount of mercury released would be no more than $482 \times 68 / 100=328 \mathrm{~kg}$. Because this mass would be released by 571,408 individuals, the average mass released from each cremation would be approximately $482 / 571 \times 68 / 100=0.574 \mathrm{~g}$. Hence, for the crematorium studied by Mills, the mass of mercury released would be 3,831 $\times 482 / 571 \times 68 / 100 \mathrm{~g}$, or $2,199 \mathrm{~g}$, and not $11,000 \mathrm{~g}$

Mills suggests that careful ground and air sampling programmes should be initiated to assess any possible hazard. In the case of ground contamination, one investigation" has shown that the mercury contamination in soil in close proximity to a crematorium is no greater than $130 \mu \mathrm{g}$ kg ' (Mansfield District Council, unpublished report). It should be noted that the number of cremations in 1989 was 2,710 and that the total number of cremations since this crematorium was opened was 63.598 (ref. 7).

Although it can be assumed that no health hazard exists to the public at large, at exposure levels below $1 \mu \mathrm{g}$ mercury $\mathrm{m}$ in ambient air, the threshold limit value for occupationally exposed individuals is $50 \mu \mathrm{g} \mathrm{m}^{-3}$ over an 8 -hour period ${ }^{x}$. In the case of crematoria, mercury may be released over an 8-hour working day, in which case the threshold limit value for this element of $50 \mathrm{ug} \mathrm{m}^{-3}$ in ambient air might be appropriate.

M. K. BASU

The Dental School H. J. WILSON

\section{The University.}

Birmingham B4 6NN, UK

Health and Safety Executive

G. KRISHNAN

\section{Masshouse Circus,}

Queensway,

Birmingham B4 7NP, UK

MILLS REPLIES - I am glad that my estimate of the amount of mercury released from crematorium chimneys is probably too large. However, in view of the importance now attached to the safe handling of even small quantities of this toxic element in laboratories and in industry, an emission of $2 \mathrm{~kg}$ of the vapour from low chimneys in urban areas is, in my opinion, completely anomalous and a real cause for concern. Also, this figure may be expected to rise because of the increasing popularity of cremation and improved long-term dental care of the general population until an effective non-mercurial substitute for amalgam becomes both available and numerically significant. I therefore continue to call for careful air and soil surveys around operating crematoria, with the methods and results to be published in the open scientific literature.

I also query the Basu et al.'s proposed threshold limit value of $50 \mu^{\mathrm{g} \mathrm{m}^{-3}}:$ because the general population (unlike a factory workforce) will include pregnant women, babies and young children, I prefer Gerstner and Huff's figure of $1 \mu \mathrm{g} \mathrm{m}^{-3}$. A limit for mercury should certainly be incorporated in regulations governing emissions from crematoria.

Department of Geology,

AlLAN Mills

The University,

Leicester LE1 7RH, UK

1. Mills, A. Nature 346, 615 (1990),

2. Todd, J.E., Walker. A.M. \& Dodd, P. Adult dent. Hith. Vol. 2 No. SS1112, pages 7, 11 (Office of Population Censuses and Surveys, HMSO, 1982)

3. Mortality Statistics by Cause Ser. DH2, No 15 (Office of Population Censuses and Surveys. HMSO, 1988).

4. Adult Dental Health 1988 SS 90/1 (Office of Population

Censuses and Surveys, HMSO, 1990)

Pharos International 56, $63(1990)$

6. Pharos international 56, 68 (1990)

Gertstner, H.B. \& Huff, J.E. J. toxic. Environ. Hith. 2 491-526 (1977).

8. HSE Occupational Exposure Limits (Guidance Note EH 40/90. 1990).

\section{Plants without chlorophyll}

SIR-dePamphilis and Palmer report that the plastid DNA of the achlorophyllous flowering plant Epifagus virginiana has lost numerous photosynthetic and $n d h$ genes, while retaining ribosomal RNA, transfer RNA and ribosomal protein genes, open reading frames and the inverted repeat - they ask "why does Epifagus maintain a plastid genome?". We suggest that the remnant genome is necessary for biosynthesis of haem for mitochondria and other organelles, which will still be required by an achlorophyllous plant.

The available evidence indicates that the carly stages of porphyrin biosynthesis in plants (leading to haem as well as chlorophyll) are restricted to plastids in non-photosynthetic as well as photosynthetic tissues. In particular, the enzymes 5-aminolaevulinic acid dehydratase and porphobilinogen deaminase (which catalyse carly steps in porphyrin biosynthesis) are confined to plastids in pea leaves and Arum spadices'. The latter enzyme is also found in plastids of Euglena, streptomycin-bleached mutants of Euglena, and Astasia longa (a morphologically similar achlorophyllous alga that, like Epifagus, retains a plastid genome depleted of genes for photosynthetic proteins').

Furthermore, plant haem is labelled by glutamate (used as a precursor in the plastid) rather than glycine (used as a precursor in mitochondria from other organisms) $)^{+}$. Within the plastid, formation of 5-aminolaevulinic acid from glutamate for porphyrin biosynthesis requires activation of the glutamate by a plastid-encoded cognate transfer RNA. Plastid DNA from achlorophyllous plants would therefore be expected to retain genes encoding at least this transfer RNA, RNA polymerase for its transcription and ribosomal proteins, ribosomal RNA and other transfer RNAs for synthesis of the RNA polymerase.

CHRISTOPHER J. HOWE

Department of Biochemistry,

University of Cambridge,

Tennis Court Road,

Cambridge CB2 1QW, UK

ALISON G. SMITH

Department of Botany

University of Cambridge,

Downing Street,

Cambridge CB2 3EA, UK

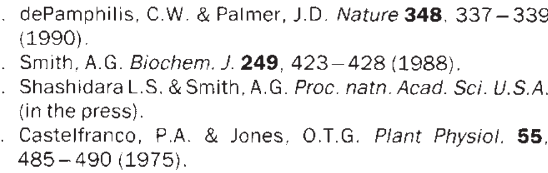

dePamphilis, C.W \& Palmer, J.D Nature $\mathbf{3 4 8}, 337-339$ 1990

Smith. A.G. Biochem. J. 249, 423-428 (1988)

Shashidara L.S. \& Smith. A.G. Proc. natn. Acad. Sci. U.S.A (in the press).

Castelfranco, P.A. \& Jones, O.T.G. Plant Physiol. 55 $485-490(1975)$

Schön, A et al Nature 322, 281-284 (1980) 